\title{
Magnitude of risk factors and in-hospital mortality of stroke in Ethiopia: a systematic review and meta-analysis
}

\author{
Muluneh Alene* ${ }^{*}$, Moges Agazhe Assemie, Leltework Yismaw and Daniel Bekele Ketema
}

\begin{abstract}
Background: The morbidity and mortality of stroke is disproportionately high in developing countries owing to the poor health care system and poor neurologic interventions. Though a number of studies were conducted to estimate the in-hospital mortality rate of stroke in Ethiopia, the lack of a nationwide study that determines the overall magnitude of risk factors and in-hospital mortality rate of stroke is an important research gap. Meta-analysis is key to improve the accuracy of estimates through the use of more data sets. Thus, this study was aimed to determine the overall magnitude of risk factors and in-hospital mortality rate of stroke in Ethiopia.

Methods: This study was conducted following the PRISMA checklist. We searched from Google Scholar, PubMed, Science Direct, Web of Science, CINAHL, and Cochrane Library databases for studies. Each of the original studies was assessed using a tool for the risk of bias adapted for cross-sectional studies. Data were pooled and a random effect meta-analysis model was fitted to provide the overall magnitude of risk factors and in-hospital mortality rate of stroke. Also, the subgroup analyses were performed to examine how the in-hospital mortality rate varies across different groups of studies.
\end{abstract}

Results: In this study, the overall magnitude of hypertension, diabetes mellitus, and atrial fibrillation among stroke patients were 47\% (95\%Cl: 40-54), 8\% (95Cl\%:6-12), and 10\% (95\%Cl: 5-19), respectively. The overall in-hospital mortality of stroke in Ethiopia was 18\% (95\%:14-22). The highest magnitude of in-hospital mortality of stroke was observed in SNNPR and the lowest was noted in Tigray region. In addition, the magnitude of the in-hospital mortality rate of stroke was $15.1 \%$ (95\%Cl: $11.3-19.4)$, and 19.6\%(95\%Cl: $14.1-25.7)$, among studies published before and after 2016, respectively.

Conclusions: Our pooled result showed that nearly one-fifth of stroke patients have died during hospitalization. The most common risk factor of stroke among the included studies was hypertension followed by atrial fibrillation and diabetes mellitus. There is a need for a better understanding of the factors associated with high blood pressure, especially in countries with a high risk of stroke.

Keywords: Mortality rate, In-hospital, Stroke, Meta-analysis

\footnotetext{
* Correspondence: mulunehadis@gmail.com

Department of Public Health, Debre Markos University, Debre Markos,

Ethiopia

(c) The Author(s). 2020 Open Access This article is licensed under a Creative Commons Attribution 4.0 International License, which permits use, sharing, adaptation, distribution and reproduction in any medium or format, as long as you give appropriate credit to the original author(s) and the source, provide a link to the Creative Commons licence, and indicate if changes were made. The images or other third party material in this article are included in the article's Creative Commons licence, unless indicated otherwise in a credit line to the material. If material is not included in the article's Creative Commons licence and your intended use is not permitted by statutory regulation or exceeds the permitted use, you will need to obtain permission directly from the copyright holder. To view a copy of this licence, visit http://creativecommons.org/licenses/by/4.0/ The Creative Commons Public Domain Dedication waiver (http://creativecommons.org/publicdomain/zero/1.0/) applies to the data made available in this article, unless otherwise stated in a credit line to the data.
} 


\section{Background}

The incidence, prevalence, and mortality rate of stroke have been increased worldwide, with most of the burden being in low and middle-income countries $[1,2]$. Globally, it is ranked as the second leading cause of death with annual mortality rate of 5.5 million, and it is now the leading cause of physical disability in peoples aged 65 years and above [3, 4]. The burden of stroke lies not only in high mortality but also high morbidity resulting in up to half of the survivors being chronically disabled $[3,5,6]$. Nearly one-fifth $(17 \%)$ of people worldwide will have a stroke in their lifetime. Developing countries have a higher burden of non-communicable diseases than the rest of the world [7]. More-than twothird (70\%) of strokes occur in low- and middle-income countries [8].

Despite the fact that Ethiopia is progressing towards universal health coverage, the country faces the double burden of both communicable and noncommunicable diseases [9]. According to WHO data published in 2017, stroke deaths in Ethiopia reached $6.23 \%$ of total deaths. In addition, the age-adjusted death rate of stroke in the country is 89.82 per 100 , 000 of the population. Previous reports that showed the future trend of stroke in SSA revealed that stroke burden will increase over the coming years owing to poor healthcare seeking behavior, and poor neurologic interventions [10]. In addition, existing studies that projected the burden of stroke in SSA between 2008 and 2025 showed that the number of people with hypertension will escalate by more-than two-third [11]. Even though, stroke is a common health problem affecting the lives of many people worldwide, its burden and risk factors are different according to geographical variation [12]. Besides, previous reports indicated that $90 \%$ of the burdens of stroke are attributable to modifiable risk factors [12]. Of this, threequarters of stroke burden is attributable to behavioral risk factors [13].

Though a number of studies were conducted to estimate the magnitude of risk factors of stroke and inhospital mortality rate in Ethiopia, the unavailability of a nationwide study that determines the magnitude of risk factors and in-hospital mortality rate of stroke is an important research gap. Meta-analysis is key to improve the accuracy of estimates through the use of more data sets. Thus, this study was aimed to determine the overall magnitude of risk factors of stroke and in-hospital mortality rate in Ethiopia.

\section{Methods}

\section{Study setting}

Ethiopia is situated in the horn of Africa, and bordered by Eritrea to the north, Sudan and South Sudan to the west, Kenya to the south, and Djibouti and Somalia to the east. The total population in the country is estimated to be more than one hundred ten million, and of which more than $84 \%$ live in rural areas. Ethiopia is a Federal Democratic Republic composed of 9 National Regional states: namely Tigray, Afar, Amhara, Oromia, Somali, BenishangulGumuz, Southern Nations Nationalities and People Region (SNNPR), Gambella and Harari, and two Administrative states (Addis Ababa City administration and Dire Dawa city council) [14]. Stroke care at the acute phase of the disease in Ethiopia is being done in hospitals preferably in an intensive care units [15].

\section{Eligibility criteria}

The eligibility of the study was determined using the following criteria:

Study design: all facility-based observational studies Study setting: all studies conducted in Ethiopia. Outcome: all studies reporting either the magnitude of risk factors of stroke or in-hospital mortality of stroke Articles: Both published and unpublished studies

\section{Searching for studies}

The comprehensive search for studies was done by two (MA and LY) of the authors between October, 15, and November 30, 2020. Google Scholar, PubMed, Web of Science, Science Direct, and CINAHL databases were searched for studies. First, articles were searched by examining the full titles ("Magnitude of risk factors and in-hospital mortality of stroke in Ethiopia") and then keywords (stroke in-hospital outcome, risk factors of stroke, Ethiopia). These keywords were used separately and in combination using Boolean operators "OR" or "AND". In addition, we searched from the reference lists of all the included studies (snowball technique) to identify any other studies those may have been missed by our search strategy. Finally, all studies were imported into reference management software (Mendeley desktop).

\section{Data extraction}

All essential data from the original studies were extracted independently by two (MA and LY) of the authors. The following information was identified for the purpose of data extraction: The last name of the first author and year of publication, the region of the study conducted, study design and period, sample size, stroke type, the magnitude of risk factors, and in-hospital mortality rate. In this study, we considered both types of ischemic (thrombotic and embolic) and hemorrhage (Intracerebral and Subarachnoid) stroke. 
Any inconsistencies in the data extraction process were decided through discussion involving all authors.

\section{Quality assessment tool}

Two reviewers (MA and MAA) assessed the quality of the included articles. The Newcastle-Ottawa Scale (NOS) adapted for cross-sectional studies was used to evaluate the quality of studies [16]. This tool was organized from three major sections. Consequently, the first section scored on the basis of one to five stars focuses on the methodological quality of each study. The second segment of the tool evaluates the comparability of the study groups with a maximum possibility of two stars to be given.

The last section of the tool is concerned with the outcomes and statistical analysis of the included studies with a maximum possibility of three stars to be given. Any inconsistent report between the two reviewers (MA and MAA) was decided by taking the average score of the two reviewers'. Finally, the assessed articles with a score of less than six out of ten were considered as achieving low quality.

\section{Data analysis}

After extracting all relevant data using Microsoft excel software, data were exported to $\mathrm{R} 3.6 .1$ version software for meta-analysis. The double arcsine transformation which stabilizes the sampling variance was applied to estimate the weighted average magnitude of risk factors of stroke and in-hospital mortality, and the transformed summary are converted back for ease of interpretation [15]. We assessed the consistency of studies using $I^{2}$ test statistics [16]. This test evaluates the null hypothesis of all the original studies that examines the same effect. In this study, there was considerable heterogeneity between the original studies $\left(I^{2}=84 \%, p<0.01\right)$. A random effect model is needed, and to account for between-study variance a random effect meta-analysis with an estimation of DerSimonian and Laird method was performed.

Univariate meta-regression was employed to explore how the study characteristics associated with the outcome of interest. In addition, the subgroup analyses were performed to investigate how the in-hospital mortality of stroke varies across different groups of studies. Furthermore, a sensitivity analysis was done to identify influential articles.

\section{Results}

\section{Description of studies}

The flow chart diagram that describes the selection of studies included in this study is presented in (Fig. 1). In our search, a total of 260 published and $13 \mathrm{~Gy}$ literatures were identified. After articles were removed by duplications, title, and reading the abstract, 49 studies were assessed for eligibility criteria. Consequently, ten studies were excluded due to the outcome of interest was not reported, having data that were not extractable and conducted in other countries. Finally, a total of 16 studies that satisfy the eligibility criteria were included in this systematic review and meta-analysis. The detailed descriptions of the included studies are presented in (Table 1). The publication year of the included studies was between 2015 and 2019. Of the total included studies, three studies were prospective facility-based studies, while the other nine studies were retrospective facility-based studies. Our summary risk of bias assessment showed that more-than two-third (68.8\%) of the studies had a low risk of bias, while $31.2 \%$ of studies had a high risk of bias. The issue of publication bias was evaluated by visual inspection of the funnel plot and using Egger's regression test. Though the funnel plot looks asymmetrical (Fig. 2), the Egger's test showed that no relationship between the effect size and its precision $(P$-value $=0.63)$.

\section{Magnitude of risk factors of stroke in Ethiopia}

The magnitude of risk factors of stroke among the included studies are presented in (Table-S1). The proportion of hypertension among stroke patients ranged from $31 \%$ [17] to $76 \%$ [21]. A total of 2, 392 stroke patients were included to determine the pooled magnitude of hypertension among stroke patients. Accordingly, our pooled analysis showed that nearly half $[47 \%$ (95\%CI: 40-54)] of stroke patients had hypertension (Fig. 3). In this review, stroke patients who had diabetes mellitus ranged from $3 \%$ [20] to $23 \%$ [17]. To determine the pooled magnitude of diabetes mellitus among stroke patients, a total of 2203 patients were included. Consequently, we found that the overall magnitude of diabetes mellitus among stroke patients was 8\% (95CI\%:6-12) (Fig. 4). Furthermore, the proportion of atrial fibrillation among stroke patients included in this study ranged from 1\% [28] to 37\% [23], and our meta-analysis revealed that one-tenth [10\% (95\%CI: 5-19)] of stroke patients had atrial fibrillation (Fig. 5).

\section{In-hospital mortality of stroke in Ethiopia}

In-hospital mortality of stroke among the included studies varies from $11 \%$ [20] to $38 \%$ [17]. A total of 2321 stroke patients were included to determine the pooled magnitude of in-hospital mortality among stroke patients, and the pooled in-hospital mortality of stroke in Ethiopia was 18\% (95\%:14-22) (Fig. 6).

The result from univariate meta-regression showed that in-hospital mortality of stroke varies by regions of the study conducted and quality score (Table 2). The 
subgroup analyses that shows how the magnitude of in-hospital mortality of stroke differs across different subgroups of studies are presented in (Table 3). Accordingly, the highest magnitude of in-hospital mortality of stroke was observed in Southern Nation's Nationalities and Peoples Region (SNNPR), and the lowest was noted in Tigray region. The subgroup analysis by publication year showed that the magnitude of the in-hospital mortality rate was $19.6 \%(95 \% \mathrm{CI}$ : 14.1-25.7) for studies published after 2016. Similarly, the magnitude of in-hospital mortality rate of stroke was $15.1 \%$ (95\%CI: 11.3-19.4) for studies published in 2016 and before.

To assess the robustness of results, first, articles which have larger than two in the absolute value of studentized residuals were screened. In the screening process article [17] seems influential (Figure S1).
Next, leave-one-out sensitivity analysis has been performed to determine whether or not they are truly influential, and it indicates that the effect is not statistically significant (Figure S2).

\section{Discussion}

This study was aimed to determine the overall magnitude of risk factors and in-hospital mortality of stroke in Ethiopia. We observed that hypertension is the most common risk factor of stroke among the included studies. Our meta-analysis showed that nearly half $(47 \%)$ of stroke patients had hypertension. Previous evidence also showed that people with hypertension are nearly four times more likely to have a stroke [31]. In addition, it has been shown that lowering blood pressure can decrease the risk of stroke by 30 to $40 \%$ [32]. Though hypertension is the main reported risk factor of stroke

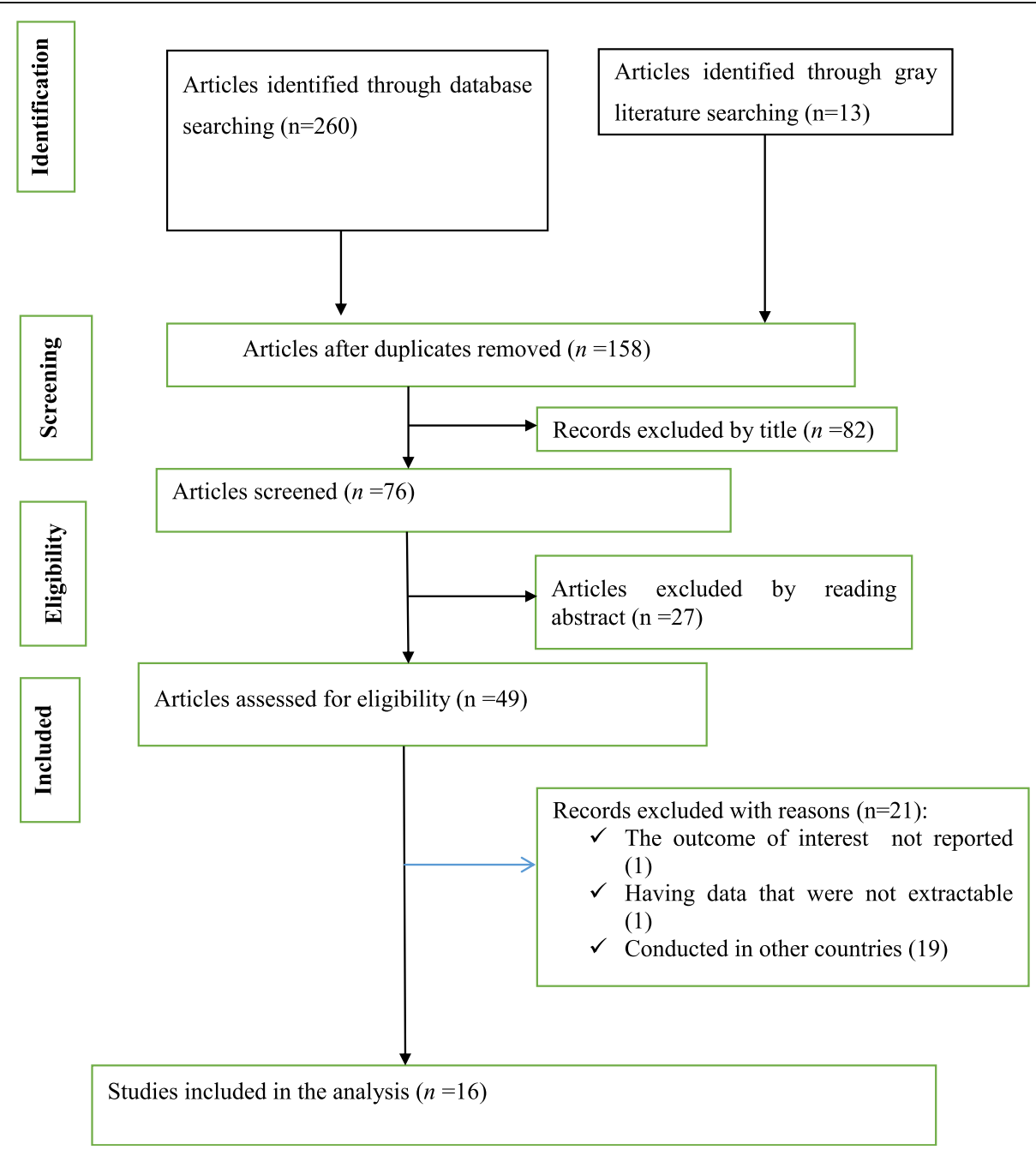

Fig. 1 Flow chart diagram that describes the selection of studies included in the systematic review and meta-analysis of magnitude of risk factors and in-hospital mortality rate of stroke in Ethiopia 
among the included studies, the proportion of hypertension among stroke patients found in the current study is lower than previous studies conducted in India, BosniaHerzegovina, Zambia, Nigeria, Malawi, and Bangladesh [33-38]. The possible explanation for this variation might be due to the lack of diagnostic modalities and proficiency [39]. Additionally, this could be due to the included studies measured hypertension in the medical record prior to the occurrence of stroke [22].

Diabetes is a well-established risk factor of stroke, and our analysis showed that diabetes mellitus is the second most common comorbidity of stroke. Nearly one-tenth $(8 \%)$ of stroke patients had diabetes mellitus. This is due to the fact that diabetes causes various microvascular and macrovascular changes often ending in major clinical complications [40]. This result is comparable with a previous study conducted in SSA [41]. However, this proportion of diabetes mellitus among stroke patients is lower than a study conducted in Nigeria and Egypt [42, 43].

The in-hospital mortality rate of stroke was the main outcome of interest, and the result found in this study showed that the overall in-hospital mortality rate of stroke in Ethiopia was 18\% (95\%:14-22). This result is comparable with other hospital-based studies conducted in sub-Saharan Africa, Cameroon, Nigeria, and Kenya [41, 44-46]. However, this result is lowerthan previous studies conducted in Ghana, Tanzania, Gambia, Uganda, and Burkina Faso [47-51]. The inhospital mortality rate of stroke was 41.1, 33.3, 41, 66.7, and $28.7 \%$ in Ghana, Tanzania, Gambia, Uganda, and Burkina Faso, respectively. The possible reason for this discrepancy could be explained by the low proportion of hypertension among stroke patients. Hypertension is usually associated with a hemorrhagic stroke which has a higher mortality rate [52].

Table 1 Characteristics of the included studies conducted in Ethiopia on magnitude of risk factors and in-hospital outcome of stroke

\begin{tabular}{|c|c|c|c|c|c|c|c|}
\hline \multirow{2}{*}{$\begin{array}{l}\text { First author and } \\
\text { publication year }\end{array}$} & \multirow[t]{2}{*}{ Region } & \multirow[t]{2}{*}{ Study design } & \multirow[t]{2}{*}{ Study period } & \multirow[t]{2}{*}{ Sample size } & \multirow{2}{*}{$\begin{array}{l}\text { In- } \\
\text { hospital } \\
\text { mortality } \\
\text { rate }\end{array}$} & \multicolumn{2}{|c|}{ Types of stroke } \\
\hline & & & & & & Ischemic & Hemorrhagic \\
\hline Asefa et al. (2018) [17] & Oromiya & $\mathrm{RCS}$ & $\begin{array}{l}\text { December } 2015 \text { to } \\
\text { November } 2017\end{array}$ & 394 & $37.87 \%$ & $35.69 \%$ & $64.31 \%$ \\
\hline Betero et al. (2019) [18] & Oromiya & $\mathrm{IBCS}$ & March 2016 to May 2019 & 111 & $16.2 \%$ & $80.1 \%$ & $18.2 \%$ \\
\hline Deresse et al. (2015) [19] & SNNPR & prospective study & May 2013 to April 2014 & 163 & $14.7 \%$ & $49.7 \%$ & $50.3 \%$ \\
\hline Erkabu et al. (2018) [20] & Amhara & $\begin{array}{l}\text { Retrospective hospital- } \\
\text { based }\end{array}$ & $\begin{array}{l}\text { February } 2014 \text { to August } \\
2016\end{array}$ & 303 & $11 \%$ & $59.4 \%$ & $40.6 \%$ \\
\hline Fekadu et al. (2019) [21] & Oromiya & Retrospective & from 2013 to 2017 & 364 & $N R$ & $52.7 \%$ & NR \\
\hline Fekadu et al. (2019) [21] & Oromiya & Prospective & March 10 to July 10, 2017 & 116 & $N R$ & $51.7 \%$ & $48.3 \%$ \\
\hline $\begin{array}{l}\text { Gebremariam et al. } \\
\text { (2016) [22] }\end{array}$ & Tigray & Retrospective case study & March 2012 to February 2014 & 142 & $12.0 \%$ & $55.6 \%$ & $32.4 \%$ \\
\hline $\begin{array}{l}\text { Gebreyohannes et al. } \\
\text { (2019) [23] }\end{array}$ & Amhara & Retrospective cohort & $\begin{array}{l}\text { November } 2012 \text { and } \\
\text { September } 2016 .\end{array}$ & $\begin{array}{l}229 \text { Ischemic } \\
\text { stroke }\end{array}$ & $12.5 \%$ & NR & NR \\
\hline Gedefa et al. (2017) [24] & $\begin{array}{l}\text { Addis } \\
\text { Abeba }\end{array}$ & $\begin{array}{l}\text { hospital based } \\
\text { retrospective study }\end{array}$ & $\begin{array}{l}\text { September } 2015 \text { to August } \\
2016\end{array}$ & 163 & $30.1 \%$ & $35.6 \%$ & $61.3 \%$ \\
\hline Greffie et al. (2015) [25] & Amhara & $\begin{array}{l}\text { Retrospective chart record } \\
\text { analysis }\end{array}$ & June 2010 to May 2013 & 98 & $13 \%$ & $69.4 \%$ & $30.6 \%$ \\
\hline $\begin{array}{l}\text { Mamushet et al. (2015) } \\
\text { [26] }\end{array}$ & $\begin{array}{l}\text { Addis } \\
\text { Abeba }\end{array}$ & Prospective & June 2008 to March 2009 & 71 & $23 \%$ & NR & NR \\
\hline Kassaw et al. (2018) [27] & $\begin{array}{l}\text { Addis } \\
\text { Abeba }\end{array}$ & Hospital based RCS & July 2015 to February 2018 & 256 & $20 \%$ & $51.2 \%$ & $37.6 \%$ \\
\hline Kefale et al. (2019) [18] & Oromiya & CS & $\begin{array}{l}\text { March 30/2016 to May30/ } \\
2019\end{array}$ & 111 & $16.2 \%$ & $80.1 \%$ & $18.2 \%$ \\
\hline Sultan et al. (2017) [28] & $\begin{array}{l}\text { Addis } \\
\text { Ababa }\end{array}$ & RCS & $\begin{array}{l}\text { December } 2010 \text { to } \\
\text { December } 2014\end{array}$ & 301 & $19.2 \%$ & $54 \%$ & $46 \%$ \\
\hline $\begin{array}{l}\text { Temesgen et al. (2018) } \\
\text { [29] }\end{array}$ & Oromiya & $\mathrm{RCS}$ & March 2012 to March 2017 & 73 & NR & $65.8 \%$ & $21.9 \%$ \\
\hline Zewdie et al. (2018) [30] & $\begin{array}{l}\text { Addis } \\
\text { Ababa }\end{array}$ & CS & August 2015 to January 2016 & 104 & NR & $44 \%$ & $56 \%$ \\
\hline
\end{tabular}

CBCS Community Based Cross Sectional Study, EDHS Ethiopia Demographic and Health Survey, HDSS Health and Demographic Surveillance System, IBCS Institution Based Cross Sectional Study, KDS-HRC Kersa Demographic Surveillance and Health Research Center, NR Not Report, SNNRP Southern Nations, Nationalities, and Peoples' Region 


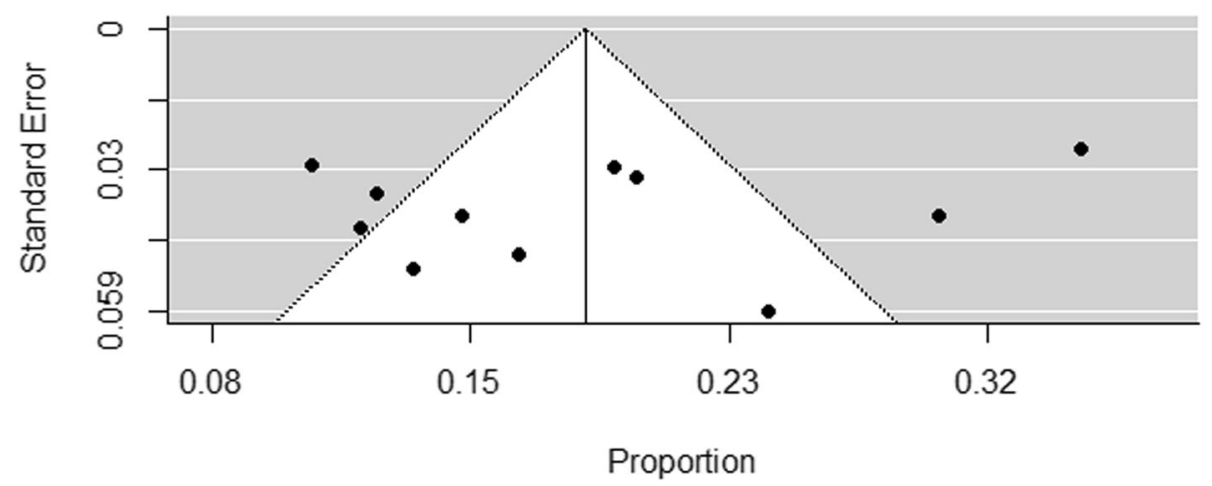

Fig. 2 Funnel plot of the in-hospital mortality rate of stroke in Ethiopia

Ischemic stroke however has a better prognosis and hypertension is not as such a very common risk factor for ischemic stroke unlike hemorrhagic stroke [53]. Hence the fact that hypertension being a less risk factor for stroke in Ethiopia, and the lower mortality can be possibly explained with this correlation. The other possible reason for this variation might be the difference in in-patient stroke care [54].

The in-hospital mortality rate of stroke in the current study was higher than previous studies conducted from Taiwan, China, Spain, and Germany [55-58]. In these countries, the in-hospital mortality of stroke was 3.1, 2.3, 7.13 , and $4.9 \%$, respectively. This variation could be explained by the advancements in stroke care and prevention, in developed countries [59].

The subgroup analyses by publication year of studies showed that the overall in-hospital mortality rate of stroke was higher among studies published after 2016 . This result is supported by a study conducted in Ghana, which reports that the rates of stroke mortality for the past three decades have increased steadily [47]. The possible reason for this trend might be the demographic transitions of populations in developing countries [9, 60]. The other possible reason might be due to the rise of non-communicable diseases in developing countries, including Ethiopia. Urbanization and

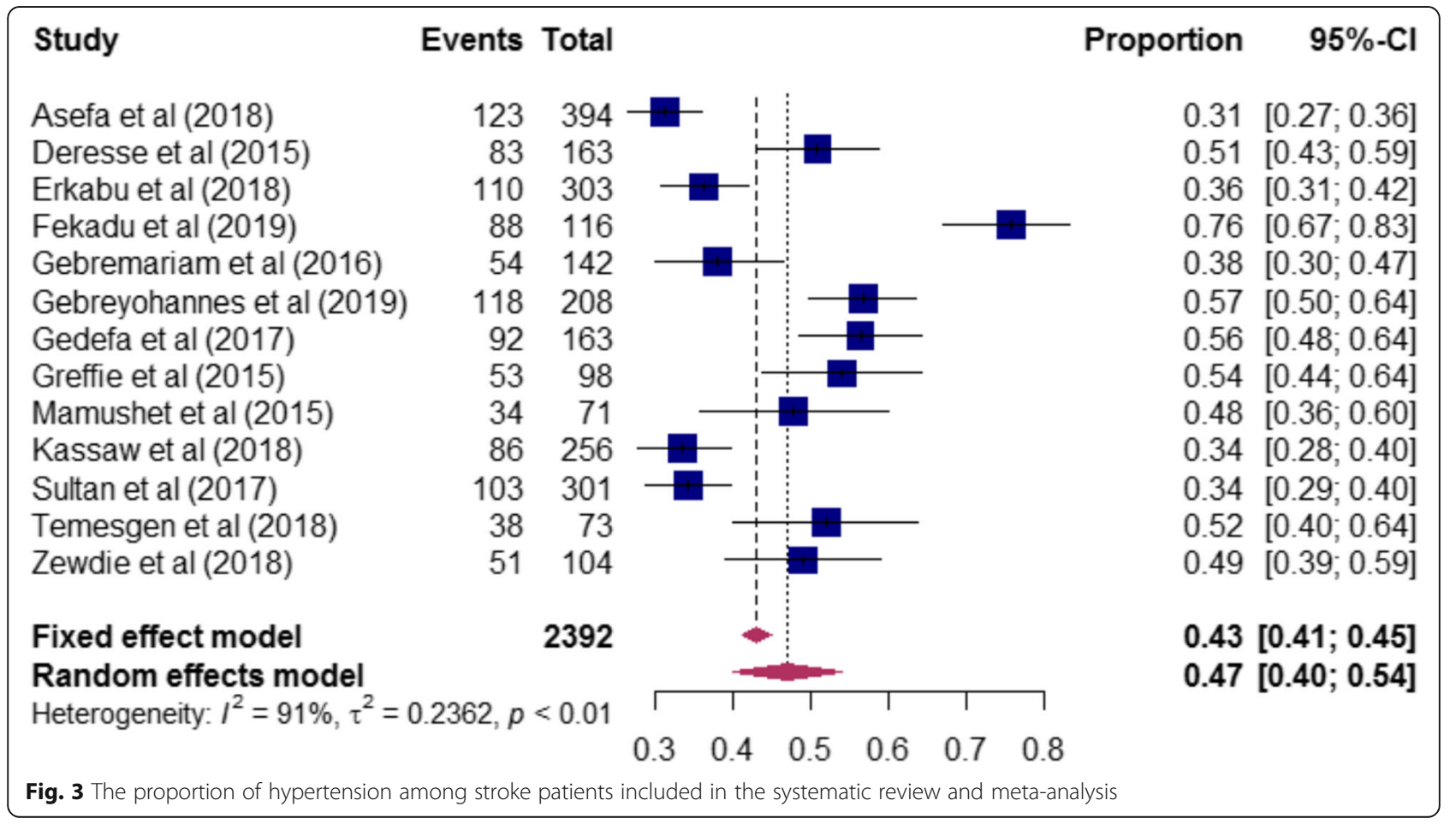




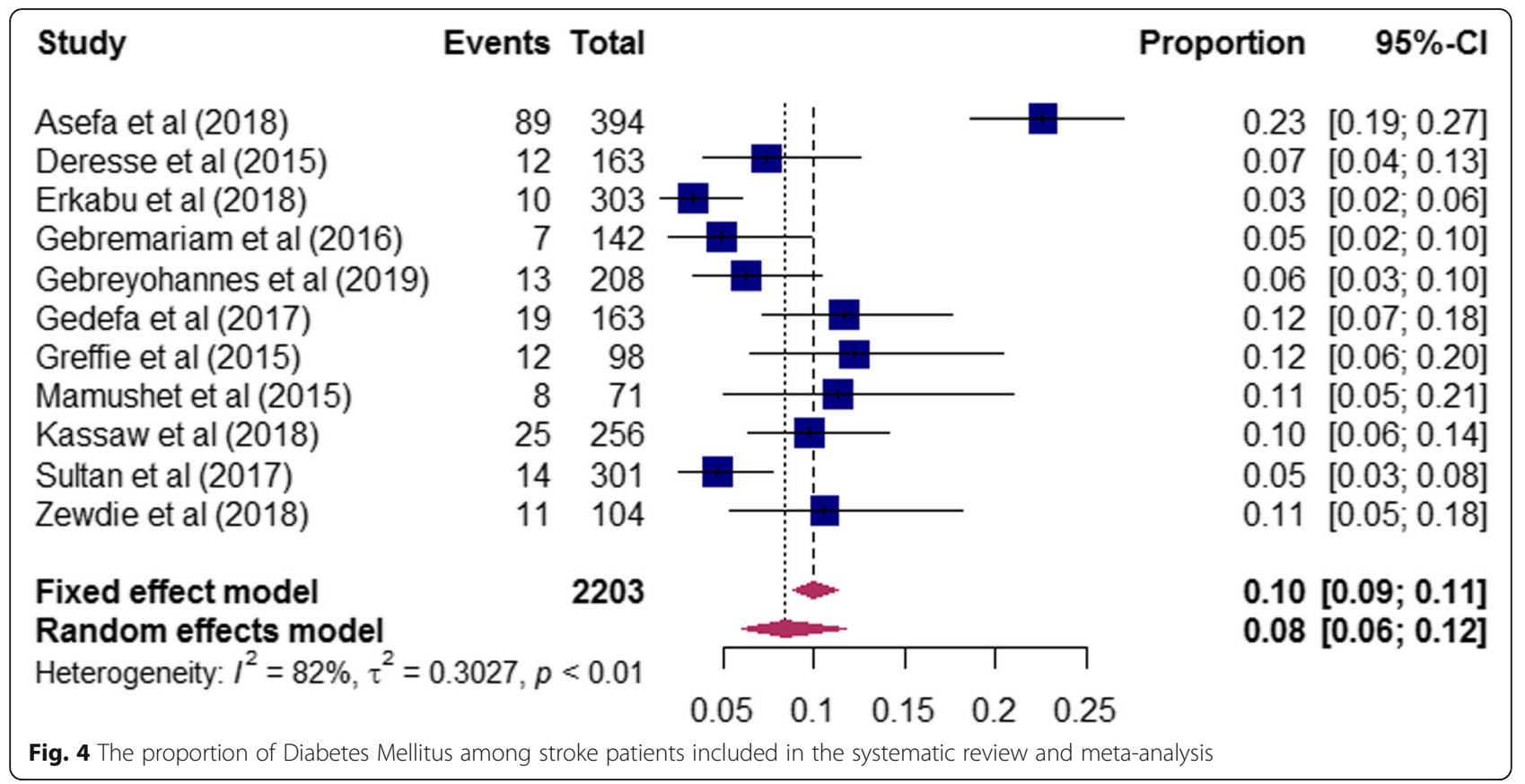

changes in lifestyle in the developing world will remain to rise the burden of stokes in the upcoming years [61]. The highest magnitude of in-hospital mortality was observed in SNNPR, while the smallest magnitude of in-hospital mortality was observed in Tigray region. This difference might be explained by the limited access to hospital care, paucity of staff, and shortage of facilities for diagnosis.

\section{Limitations}

This study was not free from limitations. There is considerable heterogeneity across the included studies. The observed heterogeneity may be described by differences in the study design, the quality of the studies, and sensitivity. Our study is mainly based on the in-patient cases, and it cannot be externally validated to the general population.

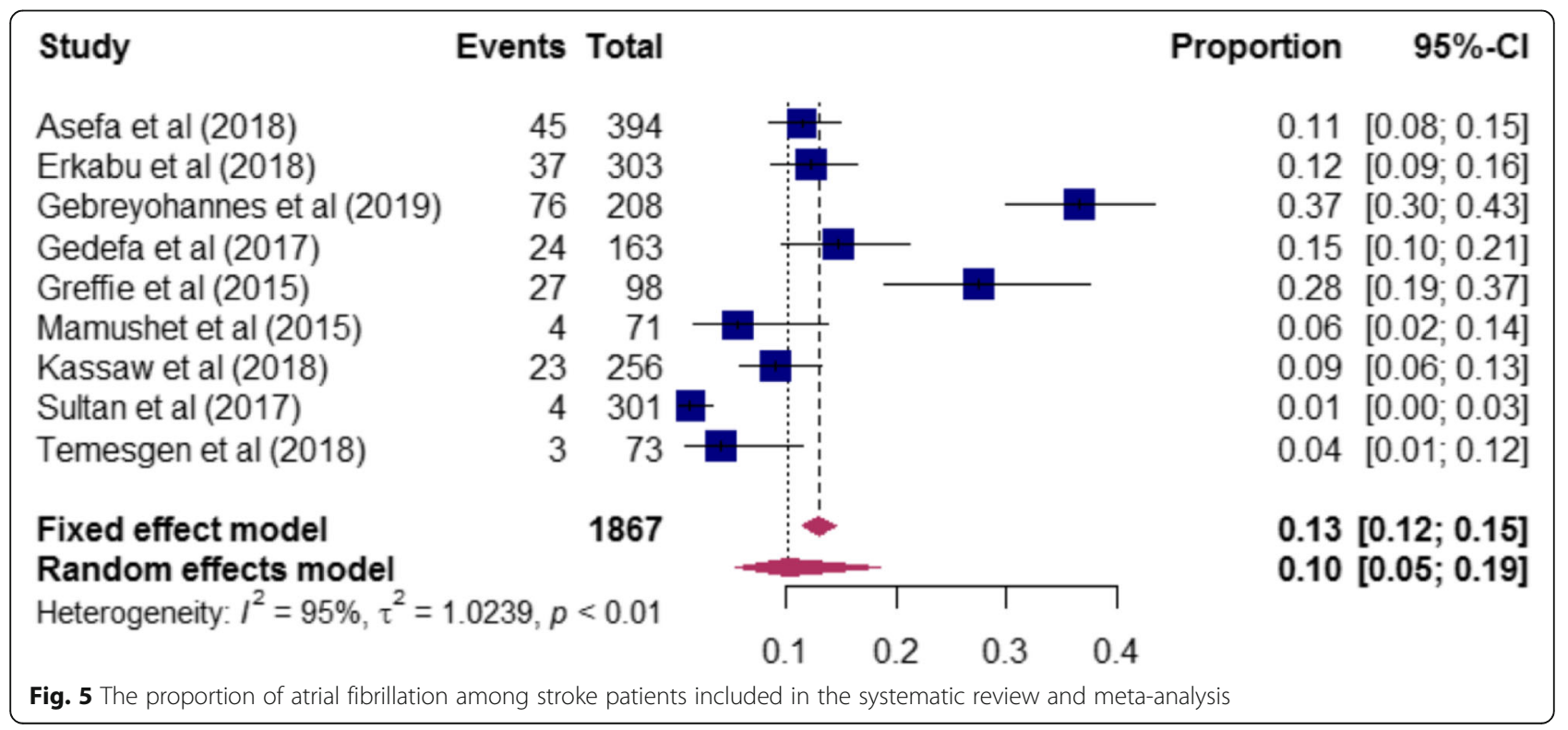




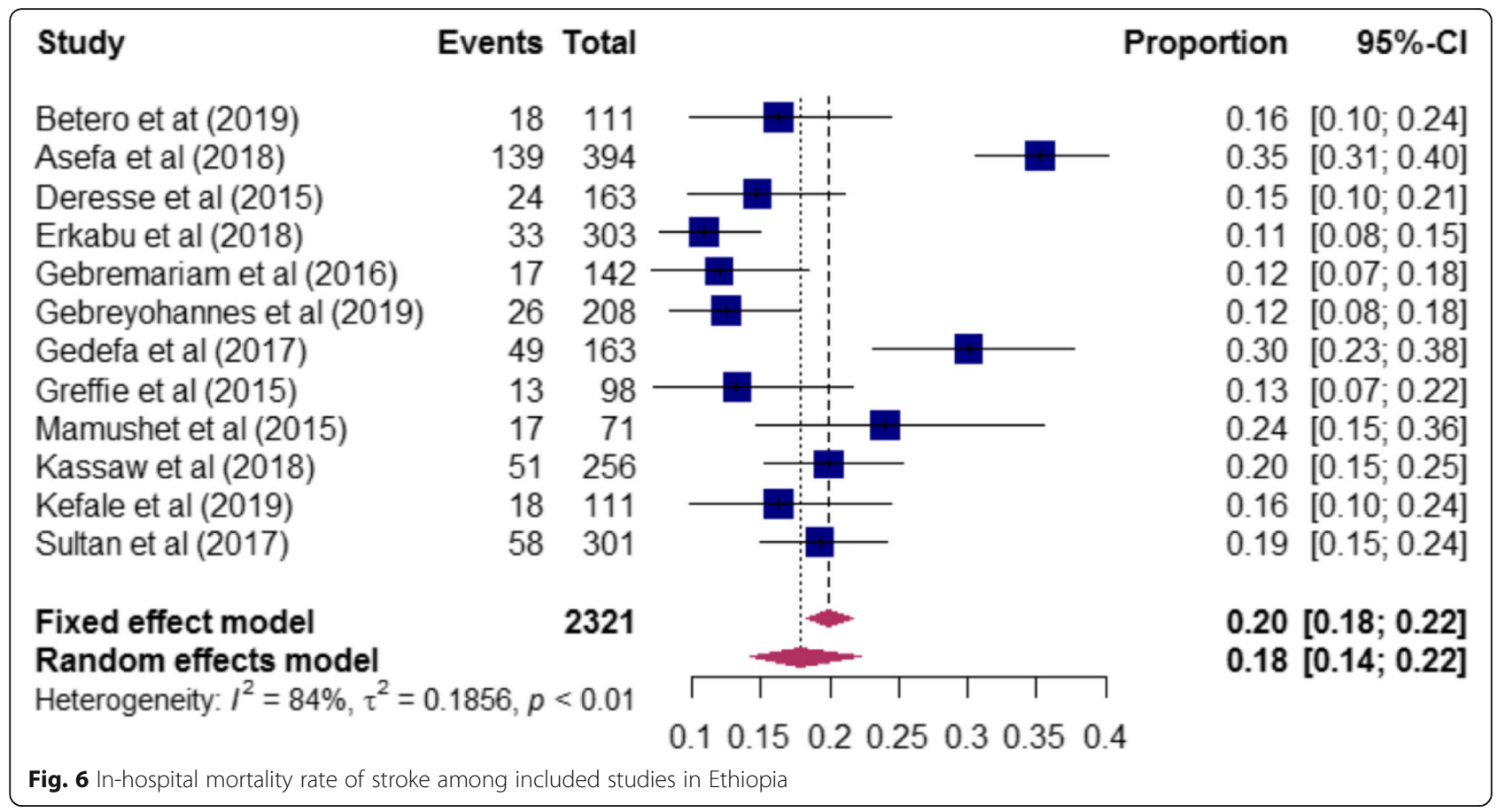

Table 2 Subgroup analysis of studies included in meta-analysis on in-hospital outcome of stroke in Ethiopia

\begin{tabular}{|c|c|c|c|c|c|}
\hline \multirow{2}{*}{$\begin{array}{l}\text { Subgroup } \\
\text { Sample size }\end{array}$} & \multirow[t]{2}{*}{$\begin{array}{l}\text { Included } \\
\text { studies }\end{array}$} & \multirow[t]{2}{*}{$\begin{array}{l}\text { In-hospital } \\
\text { mortality rate }\end{array}$} & \multirow{2}{*}{\multicolumn{3}{|c|}{$\begin{array}{l}\text { patients have died during hospitalization in Ethiopia. } \\
\text { The most common risk factor of stroke among the in- } \\
\text { cluded studies was hypertension followed by atrial fibril- }\end{array}$}} \\
\hline & & & & & \\
\hline$\leq 163$ (less-than median) & 7 & $\begin{array}{l}17.7 \% \\
(95 \% \text { Cl:13.2-22.9) }\end{array}$ & \multicolumn{3}{|c|}{$\begin{array}{l}\text { lation and diabetes mellitus. In addition, this study } \\
\text { reveals that there is an increasing trend of stroke, and its }\end{array}$} \\
\hline $\begin{array}{l}>163 \\
\text { (greater-than median) }\end{array}$ & 5 & $\begin{array}{l}18.9 \% \\
(95 \% \mathrm{Cl}: 11.5-27.7)\end{array}$ & \multicolumn{3}{|c|}{$\begin{array}{l}\text { in-hospital mortality in Ethiopia. The result of this study } \\
\text { implies that there is a need for better awareness of the }\end{array}$} \\
\hline Region & & & \multicolumn{3}{|c|}{ risk factors associated with high blood pressure, espe- } \\
\hline Amhara & 3 & $\begin{array}{l}14.7 \% \\
(95 \% \mathrm{Cl}: 9.6-20.6)\end{array}$ & \multicolumn{3}{|c|}{$\begin{array}{l}\text { cially in regions with a high burden of stroke, including } \\
\text { Ethiopia. Efforts should be focused on the primary pre- }\end{array}$} \\
\hline Oromiya & 3 & $\begin{array}{l}10.8 \% \\
(95 \% \mathrm{Cl}: 7.8-14.6)\end{array}$ & \multicolumn{3}{|c|}{ vention of non-communicable disease and stroke. } \\
\hline SNNPR & 1 & $\begin{array}{l}35.2 \% \\
(95 \% \mathrm{Cl}: 30.6-40.0)\end{array}$ & \multicolumn{3}{|c|}{$\begin{array}{l}\text { Table } 3 \text { Related factors with heterogeneity of in-hospital } \\
\text { mortality of stroke (based on univariate meta-regression) }\end{array}$} \\
\hline \multirow[t]{2}{*}{ Addis Ababa } & \multirow[t]{2}{*}{3} & \multirow{2}{*}{$\begin{array}{l}16.3 \% \\
(95 \% \mathrm{Cl}: 9.8-23.8)\end{array}$} & Sources of heterogeneity & Coefficient & $P$-value \\
\hline & & & Sample size & 0.0003 & 0.26 \\
\hline Tigray & \multirow[t]{2}{*}{1} & \multirow[t]{2}{*}{$\begin{array}{l}10.7 \% \\
(95 \% \text { Cl:7.5-14.5) }\end{array}$} & Publication year & 0.0014 & 0.94 \\
\hline Publication year & & & \multicolumn{3}{|l|}{ Quality score } \\
\hline \multirow[t]{2}{*}{2016 and before } & \multirow[t]{2}{*}{4} & \multirow{2}{*}{$\begin{array}{l}15.1 \% \\
(95 \% \text { Cl:11.3-19.4) }\end{array}$} & \multirow[t]{2}{*}{ Low } & 0.06 & 0.25 \\
\hline & & & & 0.42(constant) & $<0.0001$ \\
\hline \multirow[t]{2}{*}{ After 2016} & \multirow[t]{2}{*}{8} & \multirow{2}{*}{$\begin{array}{l}19.6 \% \\
(95 \% \mathrm{Cl}: 14.1-25.7)\end{array}$} & \multicolumn{3}{|l|}{ Religion } \\
\hline & & & Amhara & -0.1604 & 0.0175 \\
\hline \multicolumn{3}{|l|}{ Quality score } & Oromiya & -0.0287 & 0.6495 \\
\hline low & 5 & $\begin{array}{l}16.3 \% \\
(95 \% \mathrm{Cl}: 10.0-23.8)\end{array}$ & SNNPR & -0.1222 & 0.1991 \\
\hline \multirow[t]{2}{*}{ High } & \multirow[t]{2}{*}{7} & \multirow{2}{*}{$\begin{array}{l}35.2 \% \\
(95 \% \mathrm{Cl}: 30.5-40.0)\end{array}$} & Tigray & -0.1617 & 0.0933 \\
\hline & & & Addis Ababa & 0.5190 (constant) & $<0.0001$ \\
\hline
\end{tabular}

\section{Conclusions}

Our pooled result showed that nearly one-fifth of stroke patients have died during hospitalization in Ethiopia. The most common risk factor of stroke among the included studies was hypertension followed by atrial fibrillation and diabetes mellitus. In addition, this study reveals that there is an increasing trend of stroke, and its in-hospital mortality in Ethiopia. The result of this study implies that there is a need for better awareness of the risk factors associated with high blood pressure, especially in regions with a high burden of stroke, including Ethiopia. Efforts should be focused on the primary premortality of stroke (based on univariate meta-regression) 


\section{Supplementary information}

Supplementary information accompanies this paper at https://doi.org/10. 1186/s12883-020-01870-6.

Additional file 1: Figure S1. In-hospital mortality rate of stroke leaving out each study.

Additional file 2: Figure S2. plot of diagnostics.

Additional file 3: Table S1. Magnitude of risk factors of stroke among the included studies in Ethiopia.

Additional file 4: Table S2. Assessing the risk of bias for the included studies.

\section{Abbreviations}

PRISMA: Preferred Reporting Items for Systematic Reviews and MetaAnalyses; SSA: Sub-Saharan Africa; NOS: Newcastle-Ottawa Scale; WHO: World Health Organization; SNNPR: South Nations, Nationalities and People's, Region

\section{Acknowledgements \\ Authors of primary study}

\section{Authors' contributions}

MA: Conception of research protocol, study design, literature review, data extraction, data analysis, interpretation and drafting the manuscript. MAA and LY contribute on data extraction, quality assessment, data analysis and manuscript review and DBK edition \& validation. All authors have read and approved the manuscript.

\section{Funding}

Not applicable.

\section{Availability of data and materials}

All data are available in the manuscript.

\section{Ethics approval and consent to participate}

Not applicable.

\section{Consent for publication}

Not applicable.

\section{Competing interests}

The authors declare that they have no competing interests.

Received: 7 March 2020 Accepted: 23 July 2020

Published online: 19 August 2020

\section{References}

1. Yan LL, Li C, Chen J, Miranda JJ, Luo R, Bettger J, Zhu Y, Feigin V, O'Donnell M, Zhao D, Wu Y. Prevention, management, and rehabilitation of stroke in low-and middle-income countries. Eneurologicalsci. 2016;2:21-30.

2. Mukherjee D, Patil CG. Epidemiology and the global burden of stroke. World Neurosurg. 2011;76(6):S85-90.

3. Lopez AD, Mathers CD, Ezzati M, Jamison DT, Murray CJ. Global and regional burden of disease and risk factors, 2001: systematic analysis of population health data. Lancet. 2006;367(9524):1747-57.

4. Howard VJ. Reference module in neuroscience and biobehavioral psychology; 2018.

5. Warlow CP. Epidemiology of stroke. Lancet. 1998;352:S1-4.

6. Caplan LR. Stroke: A clinical approach. Butterworth: Heinemann; 1993.

7. Owolabi M, Sarfo FS, Akinyemi R, Gebreyohanns M, Ovbiagele B. The SubSaharan Africa Conference on Stroke (SSACS): an idea whose time has come. J Neurol Sci. 2019;400:194-8.

8. World Stroke Organization. Facts and Figures about Stroke. https://www world-stroke.org/component/content/article/16-forpatients/84-facts-andfigures-about-stroke. Accessed 18 Nov 2019.

9. Misganaw A, Haregu TN, Deribe K, Tessema GA, Deribew A, Melaku YA, Amare AT, Abera SF, Gedefaw M, Dessalegn M, Lakew Y. National mortality burden due to communicable, non-communicable, and other diseases in
Ethiopia, 1990-2015: findings from the global burden of disease study 2015 Popul Health Metrics. 2017;15(1):29.

10. BeLue R, Okoror TA, Iwelunmor J, Taylor KD, Degboe AN, Agyemang C, Ogedegbe $\mathrm{G}$. An overview of cardiovascular risk factor burden in subSaharan African countries: a socio-cultural perspective. Glob Health. 2009; 5(1):10.

11. Mayosi BM. The 10 'Best Buys' to combat heart disease, diabetes and stroke in Africa; 2013. p. 973-4.

12. Feigin $V L$, Roth $G A$, Naghavi $M$, Parmar $P$, Krishnamurthi $R$, Chugh $S$, Mensah GA, Norrving B, Shiue I, Ng M, Estep K. Global burden of stroke and risk factors in 188 countries, during 1990-2013: a systematic analysis for the Global Burden of Disease Study 2013. Lancet Neurol. 2016;15(9):913-24.

13. Jones $P$, Jones $D$. Stroke 2: primary and secondary prevention strategies. Nurs Times. 2017;113(12):42-6.

14. Central Statistical Agency (CSA) [Ethiopia] and ICF. Ethiopia Demographic and Health Survey 2016. Addis Ababa and Rockville: CSA and ICF; 2016.

15. FoMH. Guidelines on clinical and programmatic management of major non communicable diseases. 2016.

16. Newcastle-Ottawa Scale customized for cross-sectional studies In. available from https://static-content.springer.com/esm/.../12889_2012_5111_ MOESM3_ESM.doc.

17. Beyene DT, Asefa H. A two year retrospective cross-sectional study on prevalence, associated factors and treatment outcome among patients admitted to medical ward (stroke unit) at Jimma University Medical Center, Jimma, South West, Ethiopia, 2018. Palliat Med Care. 2018;5(4):1-6.

18. Kefale B, Betero G, Temesgen G, Degu A. Management practice, and treatment outcome and its associated factors among hospitalized stroke patient at Ambo University Referral Hospital, Ethiopia: an Institutional Based Cross Sectional Study.

19. Deresse B, Shaweno D. Epidemiology and in-hospital outcome of stroke in South Ethiopia. J Neurol Sci. 2015;355(1-2):138-42.

20. Erkabu SG, Agedie Y, Mihretu DD, Semere A, Alemu YM. Ischemic and hemorrhagic stroke in Bahir Dar, Ethiopia: a retrospective hospital-based study. J Stroke Cerebrovasc Dis. 2018;27(6):1533-8.

21. Fekadu G, Chelkeba L, Kebede A. Risk factors, clinical presentations and predictors of stroke among adult patients admitted to stroke unit of Jimma university medical center, south West Ethiopia: prospective observational study. BMC Neurol. 2019:19(1):183.

22. Gebremariam SA, Yang HS. Types, risk profiles, and outcomes of stroke patients in a tertiary teaching hospital in northern Ethiopia. eNeurologicalSci. 2016;3:41-7.

23. Gebreyohannes EA, Bhagavathula AS, Abebe TB, Seid MA, Haile KT. Inhospital mortality among ischemic stroke patients in Gondar University Hospital: a retrospective cohort study. Stroke Res Treat. 2019;2019:7275063.

24. Gedefa B, Menna T, Berhe T, Abera H. Assessment of risk factors and treatment outcome of stroke admissions at St. Paul's teaching hospital, addis ababa, Ethiopia. J Neurol Neurophysiol. 2017;8(3):1-6.

25. Greffie ES, Mitiku T, Getahun S. Risk factors, clinical pattern and outcome of stroke in a referral hospital, Northwest Ethiopia. Clin Med Res. 2015;4(6):182-8.

26. Mamushet $Y$, Zenebe $G$, Addissie A. Medical and neurological complications among stroke patients admitted for inpatient care in Addis Ababa, Ethiopia. Ethiop Med J. 2015;53(1):9-17.

27. Kassaw A, Cherie A,Bedada T. Prevalence of stroke, the nursing managements provided and outcomes of stroke patients admitted to Tikur Anbessa Specialized Hospital (TASH) from July1/2015 to Feb30/2018, Addis Ababa, Ethiopia, 2018. accessed from http://etd.aau.edu.et/handle/123456 789/13488? show=full.

28. Sultan M, Debebe F, Azazh A, Hassen GW. Epidemiology of stroke patients in Tikur Anbessa specialized hospital: emphasizing clinical characteristics of hemorrhagic stroke patients. Ethiop J Health Dev. 2017;31(1):13-7.

29. Temesgen TG, Teshome B, Njogu P. Treatment outcomes and associated factors among hospitalized stroke patients at Shashemene Referral Hospital, Ethiopia. Stroke Res Treat. 2018;2018.

30. Zewdie A, Debebe F, Kebede S, Azazh A, Laytin A, Pashmforoosh G, Hassen GW. Prospective assessment of patients with stroke in Tikur Anbessa specialised hospital, Addis Ababa, Ethiopia. Afr J Emerg Med. 2018;8(1):21-4.

31. Chobanian AV, Bakris GL, Black HR, Cushman WC, Green LA, Izzo JL Jr, Jones DW, Materson BJ, Oparil S, Wright JT Jr, Roccella EJ. Seventh report of the joint national committee on prevention, detection, evaluation, and treatment of high blood pressure. Hypertension. 2003;42(6):1206-52. 
32. Lawes $C M$, Bennett DA, Feigin VL, Rodgers A. Blood pressure and stroke: an overview of published reviews. Stroke. 2004;35(3):776-85.

33. Pathak A, Kumar P, Pandit AK, Chakravarty K, Misra S, Yadav AK, Prasad K. Is prevalence of hypertension increasing in first-ever stroke patients?: a hospital-based cross-sectional study. Ann Neurosci. 2018;25(4):219-22.

34. Bender M, Jusufovic E, Railic V, Kelava S, Tinjak S, Dzevdetbegovic D, Mot D, Tresnjo M, Lakicevic S, Pejanovic-Skobic N, Sinanovic O. High burden of stroke risk factors in developing country: the case study of BosniaHerzegovina. Mater Soc-Med. 2017;29(4):277.

35. Heikinheimo T, Chimbayo D, Kumwenda JJ, Kampondeni S, Allain TJ. Stroke outcomes in Malawi, a country with high prevalence of HIV: a prospective follow-up study. PLoS One. 2012;7(3):e33765.

36. Owolabi LF, Nagoda M. Stroke in developing countries: experience at Kano, Northwestern Nigeria. Sudan J Med Sci. 2012;7(1):9.

37. Watila MM, Nyandaiti YW, Ibrahim A, Balarabe SA, Gezawa ID, Bakki B, Tahir A, Sulaiman MM, Bwala SA. Risk factor profile among black stroke patients in Northeastern Nigeria. J Neurosci Behav Health. 2012;4(5):50-8.

38. Hossain AM, Ahmed NU, Rahman M, Islam MR, Sadhya G, Fatema K. Analysis of sociodemographic and clinical factors associated with hospitalized stroke patients of Bangladesh. Faridpur Med Coll J. 2011;6(1):19-23.

39. Mulugeta H, Yehuala A, Haile D, Mekonnen N, Dessie G, Kassa GM, Kassa ZS, Habtewold TD. Magnitude, risk factors and outcomes of stroke at Debre Markos Referral Hospital, Northwest Ethiopia: a retrospective observational study. Egypt J Neurol Psychiatry Neurosurg. 2020;56:1-9.

40. Chen R, Ovbiagele B, Feng W. Diabetes and stroke: epidemiology, pathophysiology, pharmaceuticals and outcomes. Am J Med Sci. 2016; 351(4):380-6.

41. Lekoubou A, Clovis N, Dzudie A, Kengne AP. Diagnosed diabetes mellitus and in-hospital stroke mortality in a major sub-Saharan African urban medical unit. Prim Care Diabetes. 2017;11(1):57-62.

42. Owolabi L, Nagode M, Ibrahim A, Uloko A, Gezawa I, Datti M. Stroke in patients with diabetes mellitus: a study from North Western Nigeria. Afr Health Sci. 2016;16(3):781-9.

43. Soliman RH, Oraby Ml, Fathy M, Essam AM. Risk factors of acute ischemic stroke in patients presented to Beni-Suef University Hospital: prevalence and relation to stroke severity at presentation. Egypt J Neurol Psychiatr Neurosurg. 2018;54(1):1-9.

44. Nkoke C, Lekoubou A, Balti E, Kengne AP. Stroke mortality and its determinants in a resource-limited setting: a prospective cohort study in Yaounde. Cameroon J Neurol Sci. 2015;358(1-2):113-7.

45. Danesi MA, Okubadejo NU, Ojini FI, Ojo OO. Incidence and 30-day case fatality rate of first-ever stroke in urban Nigeria: the prospective community based Epidemiology of Stroke in Lagos (EPISIL) phase II results. J Neurol Sci. 2013;331(1-2):43-7.

46. Kaduka L, Muniu E, Oduor C, Mbui J, Gakunga R, Kwasa J, Wabwire S, Okerosi N, Korir A, Remick S. Stroke mortality in Kenya's public tertiary hospitals: a prospective facility-based study. Cerebrovasc Dis Extra. 2018;8(2):70-9.

47. Sarfo FS, Akassi J, Awuah D, Adamu S, Nkyi C, Owolabi M, Ovbiagele B. Trends in stroke admission and mortality rates from 1983 to 2013 in central Ghana. J Neurol Sci. 2015;357(1-2):240-5.

48. Okeng'o K, Chillo P, Gray WK, Walker RW, Matuja W. Early mortality and associated factors among patients with stroke admitted to a large teaching hospital in Tanzania. J Stroke Cerebrovasc Dis. 2017:26(4):871-8.

49. Garbusinski JM, van der Sande MA, Bartholome EJ, Dramaix M, Gaye A, Coleman R, Nyan OA, Walker RW, McAdam KP, Walraven GE. Stroke presentation and outcome in developing countries: a prospective study in the Gambia. Stroke. 2005;36(7):1388-93.

50. Nakibuuka J, Sajatovic M, Nankabirwa J, Ssendikadiwa C, Furlan AJ, Katabira E, Kayima J, Kalema N, Byakika-Tusiime J, Ddumba E. Early mortality and functional outcome after acute stroke in Uganda: prospective study with 30 day follow-up. Springerplus. 2015;4(1):450.

51. Labodi LD, Kadri C, Valentin YN, Christian N, Jean KB. Intra-hospital mortality of stroke and its predictive factors in a reference hospital in Ouagadougou, Burkina Faso. Brain. 2017;1(3):1-6.

52. An SJ, Kim TJ, Yoon BW. Epidemiology, risk factors, and clinical features of intracerebral hemorrhage: an update. J Stroke. 2017;19(1):3.

53. Boehme AK, Esenwa C, Elkind MS. Stroke risk factors, genetics, and prevention. Circ Res. 2017;120(3):472-95.

54. Venugopalan WY, Bhatia R, Pandian J, Khurana D, Kaul S, Sylaja PN, Arora D, Khatter H, Padma MV, Singhal AB. Regional differences in ischemic stroke in India (north vs. south). Int J Stroke. 2019;14(7):706-14.
55. Heuschmann PU, Kolominsky-Rabas PL, Misselwitz B, Hermanek P, Leffmann C, Janzen RW, Rother J, Buecker-Nott HJ, Berger K. Predictors of in-hospital mortality and attributable risks of death after ischemic stroke: the German Stroke Registers Study Group. Arch Intern Med. 2004;164(16):1761-8.

56. Liu M, Wu B, Wang WZ, Lee LM, Zhang SH, Kong LZ. Stroke in China: epidemiology, prevention, and management strategies. Lancet Neurol. 2007; 6(5):456-64.

57. Ong CT, Sung SF, Wong YS, Wu CS, Hsu YC, Su YH, Li CH, Hung LC. Risk factors for in-hospital mortality among ischemic stroke patients in southern Taiwan. Int J Gerontol. 2016;10(2):86-90.

58. Kortazar-Zubizarreta I, Pinedo-Brochado A, Azkune-Calle I, AguirreLarracoechea U, Gomez-Beldarrain M, Garcia-Monco JC. Predictors of inhospital mortality after ischemic stroke: a prospective, single-center study. Health Scie Rep. 2019;2(4):e110.

59. He Q, Wu C, Luo H, Wang ZY, Ma XQ, Zhao YF, Lu J, Xiang C, Qin YY, Wu SQ, Yu FF. Trends in in-hospital mortality among patients with stroke in China. PLoS One. 2014;9(3):e92763.

60. Donkor ES. Stroke in the century: a snapshot of the burden, epidemiology, and quality of life. Stroke Res Treat. 2018;2018:3238165.

61. Aminoff MJ, Boller F, Swaab DF. Neurologic aspects of systemic disease, Part III Foreword. Handb Clin Neurol. 2014;121:vii.

\section{Publisher's Note}

Springer Nature remains neutral with regard to jurisdictional claims in published maps and institutional affiliations.
Ready to submit your research? Choose BMC and benefit from:

- fast, convenient online submission

- thorough peer review by experienced researchers in your field

- rapid publication on acceptance

- support for research data, including large and complex data types

- gold Open Access which fosters wider collaboration and increased citations

- maximum visibility for your research: over $100 \mathrm{M}$ website views per year

At BMC, research is always in progress.

Learn more biomedcentral.com/submissions 